\title{
Continental Drift: Is the Euro's Fixed Exchange Rate Regime Undermining Cohesion Policy?
}

\author{
CHRISTOPHER JAMES DAY (1) \\ University of Cambridge, Department of Land Economy, 16-21 Silver Street, \\ Cambridge CB3 9EP, UK. Email: cjd76@cantab.ac.uk
}

The ravages of two world wars and a desire to develop a politically and economically united Europe led to the establishment of the Eurozone in January 1999. The European Monetary Union was a grand experiment that brought 11 European nations under a single currency, the euro. Complexities associated with the implementation of effective fiscal, budgetary and banking coordination left the bloc vulnerable to asymmetries in the productivity and factor markets of its members. This article analyses how adoption of the euro, which prevented nominal exchange rate adjustments, impacted on the competitiveness and real economies of member states, thereby undermining the European Union's key priority of creating balanced economic growth and productivity.

\section{Introduction}

The establishment of the Eurozone in January 1999 marked a significant step towards the European Union's (EU's) goal of 'ever closer union'. Notwithstanding, the absence of sufficient fiscal and budgetary coordination has created tensions between the diverse economies of the European Monetary Union (EMU) (Baldwin and Wyplosz 2012; De Grawe 2012; Stiglitz 2016). These issues adversely impact the EU's key priority of creating balanced economic growth, competitiveness and productivity (Atkinson 2001).

The Eurozone's economic problems have been growing since its inception in 1999 (Arestis and Sawyer 2012; Stiglitz 2016). A failure by policymakers to address asymmetries in productivity across European economies and difficulties in converging real 
economic factors has led to a gradual divergence in European inflation and competitiveness across member states (Arestis and Sawyer 2012). This situation is suboptimal.

Previous literature has examined both the European debt crisis and the degree to which the Eurozone forms an optimum currency area (OCA) (Arestis and Sawyer 2012; Baldwin and Wyplosz 2012; De Grawe 2012). The literature is yet to examine the scale of currency distortions within the EMU and survey how these have impacted on the real economies of Eurozone members. Accordingly, this paper seeks to estimate the extent to with which real exchange rates have deviated from equilibria within constituent states and whether these distortions have had a significant effect on gross domestic product (GDP), unemployment, budget positions and current account balances for individual Eurozone members.

This article has a twofold motivation. First, the EU has spent hundreds of billions of euros on 'cohesion policy' which seeks to balance European competitiveness and productivity (DG Regio 2017). These efforts are likely to have been undermined by the effect that currency distortions have on an individual nation's competitiveness. For instance, Eurozone members have experienced asymmetric inflation since the late 1990s (Sinn 2014; Bernanke 2015). In the absence of nominal adjustments, this has had a profound effect on the real exchange rates of EMU members. Consequently, Germany's level of competitiveness has been abnormally strong, at the expense of peripheral members. This has been reflected in Germany's record low unemployment, strong economic growth and enormous current account surplus (Eurostat 2017; Bohme 2018; Sachgau and Skolimowski 2018).

Second, the absence of fiscal integration within the Eurozone fails to conform to OCA theory. Without a large central budget, the EU is unable to make substantial fiscal transfers between surplus and deficit nations (Arestis and Sawyer 2012). This is problematic given the reticence of individual nations to provide transfer payments and a tendency for bailout packages to be linked with austerity measures (Arestis and Sawyer 2012; Kitsantonis 2018). These views are valid given the problems associated with 'free rider' members when the burden of fiscal irresponsibility is shared. For example, Germany feels it is carrying the burden of Europe, in turn making it reluctant to provide debt relief to other EMU nations (Reuters 2017). Without proper fiscal integration, peripheral economies can only adjust their competitiveness through prices and wages. This will prolong a painful period of deflation, high unemployment and low productivity for deficit members (Arestis and Sawyer 2012; Eurostat 2018). A failure to address this issue will exacerbate distortions as peripheral economies become even less competitive (Stiglitz 2016).

Given the euro's youthfulness compared with other major currencies, such as the United States dollar, and the dynamic process of OCAs, it is to be expected that the European Monetary Union will have a successful future. Addressing the issues considered in this article will facilitate this outcome.

This article makes several contributions to the literature. First, it estimates the magnitude of currency distortions within the EMU, which suggests that a large proportion of Germany's recent economic success may well have come at the cost of 
fellow Eurozone members. Germany has benefited from the euro by amassing a significant current account surplus. Second, the article demonstrates how these distortions have manifested themselves in the Eurozone's real economy, thereby undermining the effectiveness of European cohesion policies.

These findings have significant policy implications. If Europe is to achieve its goal of balanced competitiveness and productivity, policymakers should work towards greater budgetary integration through agreed mechanisms for fiscal transfers. ${ }^{1}$ Transfer payments from wealthy members, such as Germany, should be viewed as rebalancing payments which offset the effect of currency distortions on national competitiveness. Notwithstanding, peripheral Eurozone members should continue to make structural reforms designed to improve their competitiveness in order to reduce future reliance on fiscal transfers. Overall, this article supports the literature on OCAs by reinforcing the need for greater fiscal integration within the political union.

\section{Theory Development}

Europe does not completely satisfy the criteria of an OCA, particularly with respect to budgetary union. Instead, emphasis was placed on delivering inflation and interest rate convergence (Arestis and Sawyer 2012). Notwithstanding, a period of economic stability between the mid-1980s and 1992 led to the European Monetary System being hailed as 'having achieved its goal of stabilizing exchange rates among member states of the EEC (European Economic Community), enabling them to move confidently forward to the next step of establishing a common currency' (Neal 2007, 102).

By the early 1990s, worrying signs were emerging as nations seeking to maintain a peg with the Deutschmark suffered as a result of Germany's tight monetary policy stance. This forced Finland out of the Exchange Rate Mechanism (ERM), after which the Finnish Markka depreciated sharply. Similar tensions were experienced in Spain, Portugal and the UK whose currencies were either devalued or withdrawn from the ERM (Neal 2007). Following withdrawal, the UK's economy picked up as exports rebounded in response to a fall in the value of the pound. In contrast, France maintained the peg to the detriment of its economy, which was suffering from high unemployment and slow growth. By July 1993, France declared that the situation was untenable.

In the run up to the establishment of the EMU, interest rate spreads declined (Baldwin and Wyplosz 2012). This lowered borrowing costs, especially for many peripheral members, in turn stimulating investment, incomes, growth and inflation (Sinn and Koll 2000; ECB 2006; Sinn 2010; De Grawe 2012). Southern European countries benefited from low borrowing costs given the introduction of a fixed exchange rate and commitment from other members to prevent their currency value from depreciating (Neal 2007; James 2012). This led to an unsustainable credit boom used to fund an increase in public sector wages and unemployment benefits rather

1. Alternatively, the EMU could consider a looser monetary union. 


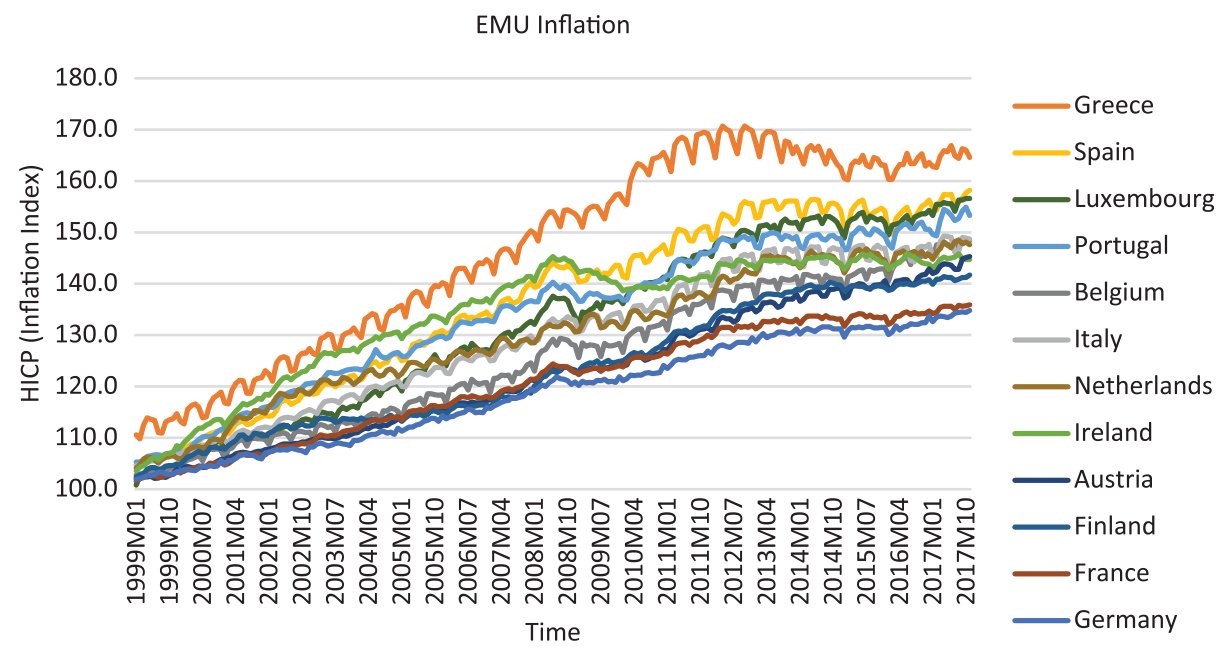

Figure 1. Eurozone Inflation between 1999 and 2017 (to view this figure in colour please see the online version of this journal).

than structural reforms to labour market rigidities (Neal 2007). For instance, the price level in Greece increased by 67\% between 1995 and 2008, 56\% in Spain, $53 \%$ in Ireland and 47\% in Portugal. Concurrently, Germany's price level increased by only $9 \%$ given its tight fiscal policy stance (Sinn 2014; Bernanke 2015). Divergence in the inflation levels of Eurozone members is illustrated in Figure 1. Sinn (2014) argues that peripheral countries not only experienced high inflation, but also an appreciation in their currencies, prior to their exchange rates being irrevocably fixed to the euro.

Following fixation to the euro, differential levels of inflation between EMU members led to diverging levels of competitiveness. According to purchasing power parity (PPP) theory, countries with low inflation, such as Germany, should experience currency appreciation (Taylor 2003). Likewise, nations with higher relative inflation, such as Greece and Spain, should see their currencies depreciate in value. As currencies are irrevocably fixed within the EMU, this prevents important adjustments from taking place through movements in the nominal exchange rate. Instead, adjustments must be undertaken through 'internal devaluations' (European Commission 2011, 21).

Whilst sound in theory, internal devaluations are likely to manifest in damaging austerity measures, a trend observable in peripheral Eurozone nations since the debt crisis (Stiglitz 2016; Kitsantonis 2018). Furthermore, prices and wages are sticky (Mankiw 2008), making adjustments through the price mechanism slow and painful (Sinn 2014; Bernanke 2015). Goldman Sachs Economics Research (2013) outlined how relative prices in Spain, Portugal and Greece need to fall by $25-35 \%$ for these nations to achieve debt sustainability. In contrast, relative prices in Germany would need to increase by at least $15-25 \%$. Of concern, empirical evidence suggests that 
prices are failing to adjust (Eurostat 2018). This will have a profound effect on real exchange rates.

The European Central Bank's (ECB) adoption of the New Consensus Macroeconomic (NCM) framework, which emphasizes price stability through manipulation of the rate of interest, has hindered the process through which adjustments can take place through the price mechanism (Arestis 2007; ECB 2018a). Given the ECB's inflation target of just under 2\% (ECB 2018b), price convergence would require peripheral EMU members to have lower levels of inflation than their richer counterparts. In such a low inflation environment, adjustments of the order of $20 \%$ would take at least a decade. Given that the ECB can only target inflation for the EMU as whole, consistently achieving the required inflation differentials amongst EMU members will prove extremely problematic and require coordination of fiscal policy. Essentially, low and stable inflation, promoted by NCM, restricts the ability of the price mechanism to realign differentials and restore competitiveness to peripheral members.

Distortions to real exchange rates, within the EMU, are extremely problematic given their effect on national competitiveness. Competitiveness is defined as the degree to which, under open market conditions, a country can produce goods and services that meet the test of foreign competition while simultaneously maintaining and expanding domestic real income' (OECD 1992, 237). It is enhanced by low real exchange rates. For instance, low German inflation resulted in a depreciation of its real exchange rate. This increased the relative competitiveness of German exports to the rest of the world (Collignon and Esposito 2014). In contrast, nations with high inflation, such as Greece and Spain, experienced a reduction in competitiveness. This made southern European economies vulnerable to rapid decline and recession when the debt crisis unfolded (ECB 2012).

This has led to the emergence of considerable trade imbalances. Whilst the last decade has seen increasing pressure fall on China to revalue its currency, which has been historically undervalued to promote exports, less attention has been directed towards Germany's trade surplus which has steadily increased since 2000 (IMF 2014; Bernanke 2015). Lucey (2017) outlines how Germany's trade surplus, in 2016, exceeded that of China's with a total value of approximately $€ 260$ billion or 9\% of GDP (Eurostat 2018). Furthermore, Germany's trade surplus accounts for nearly all the Eurozone's surplus with the rest of the world. Whilst trade surpluses are a sign of a nation's growing competitiveness and demand for its products, it is important to ascertain the extent to which Germany's enormous surplus has resulted from the effective devaluation of its real exchange rate caused by the euro (Bernanke 2015).

In the long term, current account surpluses are contrary to the EU's Macroeconomic Imbalance Procedure, which sets a limit on current account surpluses at 6\% of GDP (Deutsche Bundesbank 2013; European Commission 2012). Despite Germany frequently exceeding this threshold since 2006, German policymakers have failed to take sufficient action to reduce the surplus through increasing expenditure on infrastructure, raising German wages and introducing reforms that 
encourage greater domestic investment (Bernanke 2015; Nienaber 2018). Reluctance to decrease the surplus is exacerbating imbalances and placing European economic stability at risk by redirecting demand away from struggling Eurozone members (Bernanke 2015). ${ }^{2}$

Based on the foregoing analysis, I hypothesize that:

H1: In the absence of nominal adjustments, real exchange rates in the EMU have deviated from equilibrium.

Given the effect of real exchange rates on national competitiveness and current account imbalances, my second hypothesis examines whether currency distortions have had a significant effect on the real economy of EMU nations:

H2: Currency distortions, in the EMU, have had a significant effect on the GDP, unemployment, balance of trade, and budget positions of Eurozone members.

\section{Data}

Exchange rate data for the original 12 EMU members between 1977Q3 and 2015Q4 were obtained from the Eurostat database (Eurostat 2018). ${ }^{3}$ These data are used to forecast the hypothetical exchange rate values in the period following the establishment of the EMU. Monthly inflation data, based on the EU's Harmonized Index of Consumer Prices (HICP), were also obtained from the Eurostat database. In addition, quarterly data for my four macroeconomic indicators: GDP, unemployment, balance of trade (current and capital account) and government debt were downloaded from Eurostat. Balance of trade data for Belgium and Greece, for the year 2007, were not available from Eurostat. Instead, these data were obtained from the OECD database and converted from United States dollars to euros using historic exchange rate data accessible through the OFX database (OECD 2018; OFX 2018). Therefore, all required data are accessible from official public databases where data quality is high and regularly monitored by European Commission authorities.

\section{Research Design}

\subsection{Hypothesis 1}

Answering Hypothesis 1 requires the generation of a set of counterfactual exchange rate values which represent the currency values of the original 12 EMU members had they not joined the currency union. Given the assumptions involved in forecasting

2. History demonstrates that fixed exchange rate systems collapse when surplus countries remain unwilling to adjust (Neal 2007). Whilst German unemployment has fallen since the GFC, unemployment in peripheral countries has risen sharply (Eurostat 2018).

3. Although Greece adopted the euro in 2001, I treat it as an original member. Average exchange rate data for each quarter are downloaded. 
hypothesized exchange rate values, it is acknowledged that my results are subject to limitations. To assuage such risks, several techniques are applied.

First, I utilize autoregressive time-series forecasting methods to generate hypothesized values for each of the original 12 EMU member's currency values, against the Special Drawing Right (SDR), from 1996Q1 to 2015Q4. Whilst exchange rate data are available until January 1999 (2001 for Greece), initial examination identified that interest rates and exchange rates began to converge by the end of 1995. This followed the European Commission's decision at the Madrid Council (European Parliament 1995), in the latter part of 1995, to form a single currency (commencing on 1 January 1999). In consequence, it is considered prudent to commence my forecasting in 1996Q1. This removes the convergence effect from my analysis, with currency values being forecast to $2015 \mathrm{Q} 4$.

In order to test the accuracy of each model, I reserved data for the period 1994Q1 to 1995Q4 which are compared with the values generated by the time-series model using data from 1977Q3 to 1993Q4. The results of these tests indicate that each of my models is strong with the greatest mean absolute percentage error and Theil coefficient being less than $8 \%$ and 0.04 respectively.

Despite confidence in the power of my forecasting models, time-series forecasts should not be utilized as a complete substitute for theory (Stock and Watson 2011). Accordingly, I generated the hypothesized exchange rate values for each of the original 12 EMU members using the relationship between exchange rates and price levels or purchasing power parity (PPP).

To project the hypothesized exchange rate values using PPP, I utilized EU inflation (HICP) as the benchmark. ${ }^{4}$ The inflation levels for each of the original 12 are then compared against the EU's inflation using the formula:

Degree of required adjustment $=\mathrm{EU}$ inflation - national inflation

This value is then utilized to generate hypothesized exchange rate values for each quarter between 1999Q1 and 2015Q4.

Once the exchange rate projections were made, using both the time-series and PPP approaches, I took the actual value (conversion rate to the SDR) less the projected values to create a currency distortion coefficient (forecast error). These values were then utilized to estimate the Root Mean Square Forecast Error (RMSFE) and percentage RMSFE (as a percentage of the conversion value) as a measure of currency distortion in answer to Hypothesis 1.

\subsection{Hypothesis 2}

In order to consider whether currency distortions generated by the EMU impacted the real economies of members, I took the forecast error developed in answering

4. As sensitivity, German inflation is used as the benchmark where all 11 nations experienced higher levels of inflation than Germany. 
Hypothesis 1 and regressed these values on the GDP, unemployment, budget and balance of trade positions of the original 12 Eurozone members.

This is summarized in the following equation:

$$
\begin{aligned}
\text { Macroeconomic indicator }(t)= & \beta 0+\beta 1(\text { Currency distortion }) \\
& + \text { Macroeconomic indicator }(t-1)+\varepsilon
\end{aligned}
$$

The analysis is conducted between the period 2007Q1 and 2015Q4 given that peripheral members originally benefited from access to cheap credit following their admission into the EMU. This is likely to have initially obscured the true impact of a common currency on national competitiveness. Furthermore, 2007 was the year of the Global Financial Crisis (GFC), which subsequently precipitated the 2010 European Debt Crisis. In the period 1999 to 2007, the EMU appeared to be a major success with member countries converging through rapid growth in peripheral members (Stiglitz 2016). However, the GFC exposed the EMU's vulnerability to the asymmetric impact of economic shocks within a monetary union.

The test variable, currency distortion, is measured in two ways. Forecast is the conversion value less the value forecasted utilizing the time-series forecasting approach whilst PPP is the conversion value less the value projected by taking the difference between national and EU-wide inflation. In the interests of interpretation, both currency distortion coefficients are designed so that the values are positive when a currency is undervalued and negative when overvalued. These variables are obtained from my testing for hypothesis one.

The impact of the EMU on the real economies of the original 12 Eurozone members is captured through six macroeconomic measures.

- GDP is the gross domestic product of the nation's economy at market prices in millions of euros.

- Unemployment measures the percentage of the active population which is not in full-time employment.

- $Y_{-}$Unemployment measures the percentage of the active population (15-24) that does not currently participate in the workforce.

- Debt measures the government's consolidated gross debt as a percentage of GDP.

Real exchange rates have a substantial effect on a nation's balance of trade. In response, two balance of trade measures were employed.

- Current_Account measures the nation's current account in millions of euros.

- Current_Capital measures the current plus the capital account in millions of euros.

In order to control for the impact of omitted variable bias, the first lag of the dependent variable is included in each regression. Inclusion of the first lag is important given the strong positive correlation of macroeconomic variables over time. Whilst other lags were considered, the first lag was selected across all models to provide 
consistency after examining the correlograms for each variable. Further, the small sample size places limitations on the number of variables that can be included in the analysis. Underlying determinants for each macroeconomic variable were not included as controls in the model for two key reasons. First, this paper is not seeking to construct a model of the factors that drive each macroeconomic variable. Second, inclusion of underlying determinants is likely to have resulted in a multicollinearity issue. My test variables, Forecast and PPP, are themselves a reflection of the drivers of a nation's economic performance.

\section{Results}

\subsection{Hypothesis 1}

Hypothesis 1 posits that, in the absence of nominal exchange rate adjustments, real exchange rates amongst EMU members have deviated from their conversion values set on 1 January 1999.

Table 1 summarizes the results for the original six core members of the EMU. This includes the RMSFE and percentage RMSFE using both the autoregressive time-series forecasting approach (Panel A) and the PPP approach (Panel B). The direction of distortion indicates whether my projections suggest that the nation's currency has been over- or undervalued since its adoption of the euro. A negative distortion indicates that the currency is undervalued whilst a positive distortion suggests that the currency is overvalued.

The results in Panel A indicate that the currencies of core EMU members are undervalued by up to $30 \%$ in the extreme cases of Austria and Germany. This suggests that the economies of core members are benefiting from the EMU given the effect of a weak currency on export competitiveness. Whilst Panel A portrays a clear undervaluation of core member currencies, Panel B complicates the story. When PPP is utilized, only Germany has an undervalued currency where the magnitude of undervaluation is a modest $4.6 \%$. The currencies of the other five core members are overvalued. This result is supported in my sensitivity test where German inflation is used as the benchmark rate of inflation. In this case, all other members, both core and peripheral, experienced higher levels of inflation than Germany in the period 1999Q1 to 2015Q4.

Table 2 summarizes the results for the original six peripheral Eurozone members. Panels A and B both suggest that the currencies of the original six peripheral members are overvalued with the projected values being weaker than the conversion values. Hence, the competitiveness of these nations is likely to have been adversely affected. Whilst the degree of distortion in Panel A is larger, confidence can be drawn from the qualitatively similar nature of my forecasts.

Overall, the results suggest that Germany has benefited from its adoption of the euro given that its conversion value is weaker than projections of its value had the mark been retained. Whilst the results in Table 1 Panel A suggest that the other five core members have also profited from the euro, Table 1 Panel B 
Table 1. Degree of currency distortion for core EMU members.

\begin{tabular}{|c|c|c|c|c|c|c|}
\hline & Germany & Belgium & France & Luxembourg & The Netherlands & Austria \\
\hline \multicolumn{7}{|c|}{ Panel A: Autoregressive approach } \\
\hline RMSFE & 0.6079 & 2.2285 & 0.0949 & 3.3248 & 0.5802 & 4.4039 \\
\hline Percentage RMSFE & $31.8 \%$ & $5.52 \%$ & $1.45 \%$ & $8.24 \%$ & $26.33 \%$ & $32 \%$ \\
\hline Direction of distortion & Negative & Negative & Negative & Negative & Negative & Negative \\
\hline \multicolumn{7}{|l|}{ Panel B: PPP approach } \\
\hline RMSFE & 0.0903 & 0.2858 & 0.1113 & 4.3697 & 0.1536 & 0.3801 \\
\hline Percentage RMSFE & $4.62 \%$ & $0.71 \%$ & $1.7 \%$ & $10.83 \%$ & $6.97 \%$ & $2.76 \%$ \\
\hline Direction of distortion & Negative & Positive & Positive & Positive & Positive & Positive \\
\hline
\end{tabular}


Table 2. Degree of currency distortion for peripheral EMU members.

\begin{tabular}{lccccc}
\hline \hline & Italy & Ireland & Greece & Spain & Portugal \\
\hline Panel A: Autoregressive approach & & & & & \\
RMSFE & 962.7809 & 0.1438 & 161.4898 & 40.7161 & 105.1863 \\
Percentage RMSFE & $49.72 \%$ & $18.26 \%$ & $47.55 \%$ & $24.47 \%$ & $52.47 \%$ \\
Direction of Distortion & Positive & Positive & Positive & Positive & Positive \\
Panel B: PPP approach & & & & N/A \\
RMSFE & 129.1354 & 0.0891 & 29.0857 & 20.9129 & 17.9993 \\
Percentage RMSFE & $6.67 \%$ & $11.31 \%$ & $8.56 \%$ & $12.57 \%$ & $8.98 \%$ \\
Direction of Distortion & Positive & Positive & Positive & Positive & Positive \\
\hline \hline
\end{tabular}


suggests otherwise. The results in Panel B indicate that Germany's low inflation and dominance within Europe may have caused an abnormal proportion of benefits to flow towards it. ${ }^{5}$ This explanation lends support to data showing that Germany's trade surplus accounts for most of the EMU's trade surplus with the rest of the world. However; when interpreting these results, it is important to stress that my forecasts should be treated as effective tools for understanding the direction of real exchange rate movements but not a precise estimate of magnitude.

\subsection{Hypothesis 2}

The second hypothesis predicts that currency distortions, within the EMU, have had a significant impact on the real economies of member states.

Table 3 summarizes the results for each of the EMU's original 12 members. Given the nature of my research design, the test variables Forecast and PPP have positive values for undervalued currencies and negative ones for overvalued currencies. Therefore, I expected GDP to have a positive coefficient, unemployment variables a negative coefficient, debt a negative coefficient and balance of trade variables a positive coefficient.

Table 3 Part 10 summarizes the effect of my projected currency distortions on the German economy. In support of predictions for Hypothesis 2, Forecast has a positive coefficient, when regressed against GDP whilst both Forecast and PPP display negative and significant coefficients when regressed against Unemployment and $Y_{-}$Unemployment. Reflective of expectations, Forecast has a significant negative coefficient when regressed against Debt whilst Forecast and PPP possess positive and significant coefficients when regressed against Current_Account and Current_Capital.

The results for Germany support the hypothesis that a lower currency value leads to improved GDP, lower unemployment, reduced debt and an improved trade position. However, the strength and consistency of my results weakens amongst the other five core EMU members. Whilst most results from the other five core members are consistent, albeit weaker, there are a number of anomalies. When I regress Forecast and PPP against GDP or Unemployment for Austria, Forecast has a positive and significant coefficient whilst $P P P$ is negative and significant. Given that Forecast and $P P P$ disagree as to whether Austria is under- or overvalued by the euro, conclusions cannot be drawn. Furthermore, Belgium, France, Luxembourg and the Netherlands each have positive and significant coefficients for Forecast when regressed against Unemployment. This suggests the counterintuitive conclusion that an undervalued currency leads to higher levels of unemployment.

A possible explanation is that Germany's dominance pulls employment opportunities towards itself. Furthermore, the true magnitude of undervaluation for these other five core members may be large enough to positively benefit exports but insufficient to impact broader employment, especially in the context of technological

5. Non-Eurozone nations, such as Switzerland, Sweden, Norway and Denmark, have also amassed substantial surpluses (Economist 2017). 
Table 3. Effect of currency distortions on the real economies of EMU members.

\begin{tabular}{|c|c|c|c|c|c|c|c|c|c|c|c|c|}
\hline 1. Finland & \multicolumn{2}{|c|}{ GDP } & \multicolumn{2}{|c|}{ Unemployment } & \multicolumn{2}{|c|}{ Y_Unemployment } & \multicolumn{2}{|r|}{ Debt } & \multicolumn{2}{|c|}{ Current_Account } & \multicolumn{2}{|c|}{ Current_Capital } \\
\hline \multicolumn{13}{|c|}{ Test Variables } \\
\hline $\begin{array}{l}\text { PPP } \\
\text { Control Vari }\end{array}$ & \multicolumn{2}{|c|}{-10204.8} & \multicolumn{2}{|c|}{-4.83} & \multicolumn{2}{|c|}{-13.27} & \multicolumn{2}{|r|}{-13.91} & \multicolumn{2}{|c|}{$8958.76^{* * *}$} & \multicolumn{2}{|c|}{$8984.2^{* * *}$} \\
\hline \multicolumn{3}{|c|}{$\begin{array}{l}\text { Control Variables } \\
\text { 1st Lag }\end{array}$} & \multicolumn{2}{|c|}{$0.19 * *$} & \multicolumn{2}{|c|}{-0.05} & \multicolumn{2}{|c|}{$0.85^{* * *}$} & \multicolumn{2}{|c|}{-0.12} & \multicolumn{2}{|c|}{-0.13} \\
\hline Intercept & \multicolumn{2}{|c|}{$38364.92^{* * *}$} & \multicolumn{2}{|c|}{$5.48 * * *$} & \multicolumn{2}{|c|}{$17.89^{* * *}$} & \multicolumn{2}{|r|}{$5.03 * *$} & \multicolumn{2}{|c|}{$1660.90^{* * *}$} & \multicolumn{2}{|c|}{1715.34} \\
\hline$N$ & \multicolumn{2}{|c|}{35} & \multicolumn{2}{|c|}{35} & \multicolumn{2}{|r|}{35} & \multicolumn{2}{|r|}{35} & \multicolumn{2}{|c|}{35} & \multicolumn{2}{|c|}{35} \\
\hline R-Squared & \multirow{2}{*}{\multicolumn{2}{|c|}{$\begin{array}{l}0.32 \\
767\end{array}$}} & 0.36 & & & 0.09 & & 0.97 & & & & 46 \\
\hline F-Statistic & & & 8.81 & & & 1.52 & & 439.6 & & & & 47 \\
\hline Significance & $\mathrm{YH}$ & & YES & & & NO & & YES & & & & ES \\
\hline * significant a & * significant & $; * * *$ significan & $1 \%$. Estima & using $\mathrm{HAC}$ & tandard erro & & & & & & & \\
\hline 2. Greece & GI & & Unemp & loyment & Y_Uner & mployment & & ebt & Current_ & ccount & Current & apital \\
\hline Test Variable & & & & & & & & & & & & \\
\hline Forecast & $123.04 * * *$ & & -0.004 & & 0.01 & & -0.20 & & $-96.87 * * *$ & & $-103.14 * * *$ & \\
\hline PPP & & 14.15 & & $-0.06 * * *$ & & $-0.13 * * *$ & & -0.14 & & -33.61 & & 12.97 \\
\hline Control Vari & bles & & & & & & & & & & & \\
\hline 1st Lag & $0.24 * * *$ & $0.84 * * *$ & $0.97 * * *$ & $0.99 * * *$ & $0.99 * * *$ & $0.97 * * *$ & $0.69 * * *$ & $0.95^{* * *}$ & -0.11 & $0.60 * * *$ & -0.14 & $0.50 * * *$ \\
\hline Intercept & $64666.68 * * *$ & $8869.50^{* * *}$ & 0.25 & $-1.75^{* * *}$ & 2.41 & $-2.90 * *$ & 5.55 & 3.44 & $-24794 * * *$ & -2874.44 & $-25604 * * *$ & -951.64 \\
\hline$N$ & 35 & 35 & 35 & 35 & 35 & 35 & 35 & 35 & 35 & 35 & 31 & 31 \\
\hline R-Squared & 0.8 & 0.67 & 0.98 & 0.99 & 0.98 & 0.99 & 0.94 & 0.94 & 0.63 & 0.36 & 0.57 & 0.27 \\
\hline F-Statistic & 63.57 & 32.64 & 912.3 & 1415.04 & 664.74 & 1027.94 & 254.72 & 232.40 & 26.86 & 8.83 & 18.56 & 5.14 \\
\hline Significance & YES & YES & YES & YES & YES & YES & YES & YES & YES & YES & YES & YES \\
\hline
\end{tabular}

* significant at $10 \%$; ** significant at 5\%; *** significant at 1\%. Estimated using HAC standard errors. Data for Capital Account in 2007 could not be obtained. 


\begin{tabular}{|c|c|c|c|c|c|c|c|c|c|c|c|c|}
\hline 3. Ireland & \multicolumn{2}{|c|}{ GDP } & \multicolumn{2}{|c|}{ Unemployment } & \multicolumn{2}{|c|}{ Y_Unemployment } & \multicolumn{2}{|c|}{ Debt } & \multicolumn{2}{|c|}{ Current_Account } & \multicolumn{2}{|c|}{ Current_Capital } \\
\hline \multicolumn{13}{|c|}{ Test Variables } \\
\hline Forecast & $-78457^{* *}$ & & $21.06 * * *$ & & $36.66 * * *$ & & $268.47 * * *$ & & $-50012.68 * * *$ & & $-46170.86^{* * *}$ & \\
\hline PPP & & $48555.17 * *$ & & $-28.11^{* * *}$ & & $-47.25^{* * *}$ & & -187.50 & & $16306.01^{*}$ & & $19044.32 * *$ \\
\hline \multicolumn{13}{|c|}{ Control Variables } \\
\hline 1st Lag & $-0.35 * *$ & $-0.21 * *$ & $1 * * *$ & $1.08 * * *$ & $0.95 * * *$ & $1.03 * * *$ & $1.10 * * *$ & $1.08 * * *$ & $0.63^{* * *}$ & $0.84^{* * *}$ & $0.62 * * *$ & $0.78^{* * *}$ \\
\hline Intercept & $-12955.9 * *$ & $4744.06^{* *}$ & $3.83^{* * *}$ & $-3.19 * * *$ & $7.58 * * *$ & $-4.33^{* *}$ & $40.31 * * *$ & -20.93 & $-8539.42 * * *$ & $1654.51 * *$ & $-7979.62 * * *$ & $1784.32 * *$ \\
\hline$N$ & 35 & 35 & 35 & 35 & 35 & 35 & 35 & 35 & 35 & 35 & 35 & 35 \\
\hline $\mathrm{R}$-Squared & 0.32 & 0.19 & 0.96 & 0.97 & 0.91 & 0.92 & 0.99 & 0.98 & 0.78 & 0.75 & 0.71 & 0.67 \\
\hline F-Statistic & 7.41 & 3.71 & 373.24 & 452.54 & 169.96 & 179.87 & 1049.32 & 748.28 & 57.18 & 47.76 & 38.55 & 32.54 \\
\hline Significance & YES & YES & YES & YES & YES & YES & YES & YES & YES & YES & YES & YES \\
\hline
\end{tabular}

* significant at $10 \% ; * *$ significant at $5 \%$; *** significant at $1 \%$. Estimated using HAC standard errors.

勇

\begin{tabular}{|c|c|c|c|c|c|c|c|c|c|c|c|c|}
\hline 4. Italy & \multicolumn{2}{|c|}{ GDP } & \multicolumn{2}{|c|}{ Unemployment } & \multicolumn{2}{|c|}{ Y_Unemployment } & \multicolumn{2}{|c|}{ Debt } & \multicolumn{2}{|c|}{ Current_Account } & \multicolumn{2}{|c|}{ Current_Capital } \\
\hline \multicolumn{13}{|c|}{ Test Variables } \\
\hline Forecast & -25.03 & & $-0.01 * * *$ & & $-0.03 * * *$ & & $-0.02 * *$ & & $-25.19 * *$ & & $-30.07 * *$ & \\
\hline PPP & & -52.26 & & $-0.01^{*}$ & & $-0.03^{*}$ & & $-0.04 * * *$ & & $-138.16^{* * *}$ & & $-152.08 * * *$ \\
\hline \multicolumn{13}{|c|}{ Control Variables } \\
\hline 1st Lag & $-0.5^{* * *}$ & $-0.46 * * *$ & $0.49 * * *$ & $0.84 * * *$ & $0.40^{* * *}$ & $0.84^{* * *}$ & $0.70^{* * *}$ & $0.91 * * *$ & $0.43^{* * *}$ & $0.61^{* * *}$ & $0.34 *$ & $0.56^{* * *}$ \\
\hline Intercept & $577592.6^{* * *}$ & $580789.5^{* * *}$ & $-3.47 * *$ & 0.11 & $-15.11^{* * *}$ & 0.55 & $11.80^{* * *}$ & 4.57 & $-31179.14^{* *}$ & $-23026.61 * * *$ & $-36958.07 * *$ & $-25236.01^{* * *}$ \\
\hline$N$ & 35 & 35 & 35 & 35 & 35 & 35 & 35 & 35 & 35 & 35 & 35 & 35 \\
\hline R-Squared & 0.26 & 0.21 & 0.88 & 0.85 & 0.88 & 0.84 & 0.98 & 0.98 & 0.57 & 0.58 & 0.51 & 0.51 \\
\hline F-Statistic & 5.65 & 4.21 & 118.28 & 92.62 & 118.85 & 86.83 & 636.64 & 646.16 & 20.90 & 22.44 & 16.64 & 16.33 \\
\hline Significance & YES & YES & YES & YES & YES & YES & YES & YES & YES & YES & YES & YES \\
\hline
\end{tabular}

* significant at 10\%; ** significant at $5 \%$; *** significant at $1 \%$. Estimated using HAC standard errors. 


\begin{tabular}{|c|c|c|c|c|c|c|c|c|c|c|c|c|}
\hline \multirow{2}{*}{$\frac{5 . \text { Portugal }}{\text { Test Variabl }}$} & \multicolumn{2}{|c|}{ GDP } & \multicolumn{2}{|c|}{ Unemployment } & \multicolumn{2}{|c|}{ Y_Unemployment } & \multicolumn{2}{|c|}{ Debt } & \multicolumn{2}{|c|}{ Current_Account } & \multicolumn{2}{|c|}{ Current_Capital } \\
\hline & & & & & & & & & & & & \\
\hline Forecast & 9.64 & & 0.01 & & 1.43 & & 0.01 & & $-0.57 * * *$ & & $-55.85^{* * *}$ & \\
\hline PPP & & 212.14 & & -0.01 & & 0.14 & & -0.31 & & $-168.84^{*}$ & & -143.72 \\
\hline \multicolumn{13}{|c|}{ Control Variables } \\
\hline 1st Lag & 0.16 & 0.11 & $0.98 * * *$ & $0.95 * * *$ & $0.86^{* * *}$ & $0.93 * * *$ & $0.99 * * *$ & $0.98 * * *$ & $0.41 * * *$ & $0.88 * * *$ & $0.44 * * *$ & $0.88 * *$ \\
\hline Intercept & $38132.69 * * *$ & $43516.80^{* * *}$ & 0.98 & 0.47 & 1.43 & 5.36 & 4.42 & -2.60 & $-8920.88^{* * *}$ & $-3667.13^{* *}$ & $-8323.52 * * *$ & -3086.48 \\
\hline$N$ & 35 & 35 & 35 & 35 & 35 & 35 & 35 & 35 & 35 & 35 & 35 & 35 \\
\hline $\mathrm{R}$-Squared & 0.05 & 0.08 & 0.93 & 0.93 & 0.88 & 0.88 & 0.99 & 0.99 & 0.80 & 0.74 & 0.80 & 0.74 \\
\hline F-Statistic & 0.9 & 1.43 & 228.15 & 225.23 & 121.92 & 120.77 & 1253.54 & 1296.55 & 65.29 & 46.54 & 64.60 & 46.25 \\
\hline Significance & NO & YES & YES & YES & YES & YES & YES & YES & YES & YES & YES & YES \\
\hline
\end{tabular}

$*$ is significant at $10 \% . * *$ is significant at $5 \%$ and $* * *$ is significant at $1 \%$. Estimated using HAC standard errors.

\begin{tabular}{|c|c|c|c|c|c|c|c|c|c|c|c|c|}
\hline 6. Spain & \multicolumn{2}{|c|}{ GDP } & \multicolumn{2}{|c|}{ Unemployment } & \multicolumn{2}{|c|}{ Y_Unemployment } & \multicolumn{2}{|c|}{ Debt } & \multicolumn{2}{|c|}{ Current_Account } & \multicolumn{2}{|c|}{ Current_Capital } \\
\hline \multicolumn{13}{|c|}{ Test Variables } \\
\hline Forecast & $607.59 *$ & & $0.07 * * *$ & & $0.16^{* * *}$ & & -0.31 & & $-591.24 * * *$ & & $-712.00 * * *$ & \\
\hline PPP & & $2135.82 * *$ & & -0.08 & & -0.24 & & $-0.56^{* * *}$ & & $-1034.72 * * *$ & & $-1066.54 * * *$ \\
\hline \multicolumn{13}{|c|}{ Control Variables } \\
\hline 1st Lag & $-0.3^{* * *}$ & -0.23 & $1.04 * * *$ & $0.92 * * *$ & $1.04 * * *$ & $0.91 * * *$ & $0.88^{* * *}$ & $0.98 * * *$ & $0.47 * * *$ & $0.84^{* * *}$ & $0.39 * * *$ & $0.83^{* * *}$ \\
\hline Intercept & $378191.3^{* * *}$ & $384844.5^{* * *}$ & $3.52 * * *$ & -0.05 & $7.38 * * *$ & -1.68 & -6.25 & $-11.58 * *$ & $-34112 * * *$ & $-27341.7 * * *$ & $-40279 * * *$ & $-27970.86^{* *}$ \\
\hline$N$ & 35 & 35 & 35 & 35 & 35 & 35 & 35 & 35 & 35 & 35 & 35 & 35 \\
\hline R-Squared & 0.23 & 0.12 & 0.98 & 0.97 & 0.98 & 0.98 & 0.99 & 0.99 & 0.86 & 0.85 & 0.85 & 0.82 \\
\hline F-Statistic & 4.79 & 2.13 & 662.51 & 583.72 & 774.34 & 701.56 & 2526.65 & 3095.87 & 99.92 & 89.75 & 91.91 & 74.66 \\
\hline Significance & YES & NO & YES & YES & YES & YES & YES & YES & YES & YES & YES & YES \\
\hline
\end{tabular}

* is significant at $10 \%$. ${ }^{*}$ is significant at $5 \%$ and $* * *$ is significant at $1 \%$. Estimated using HAC standard errors. 


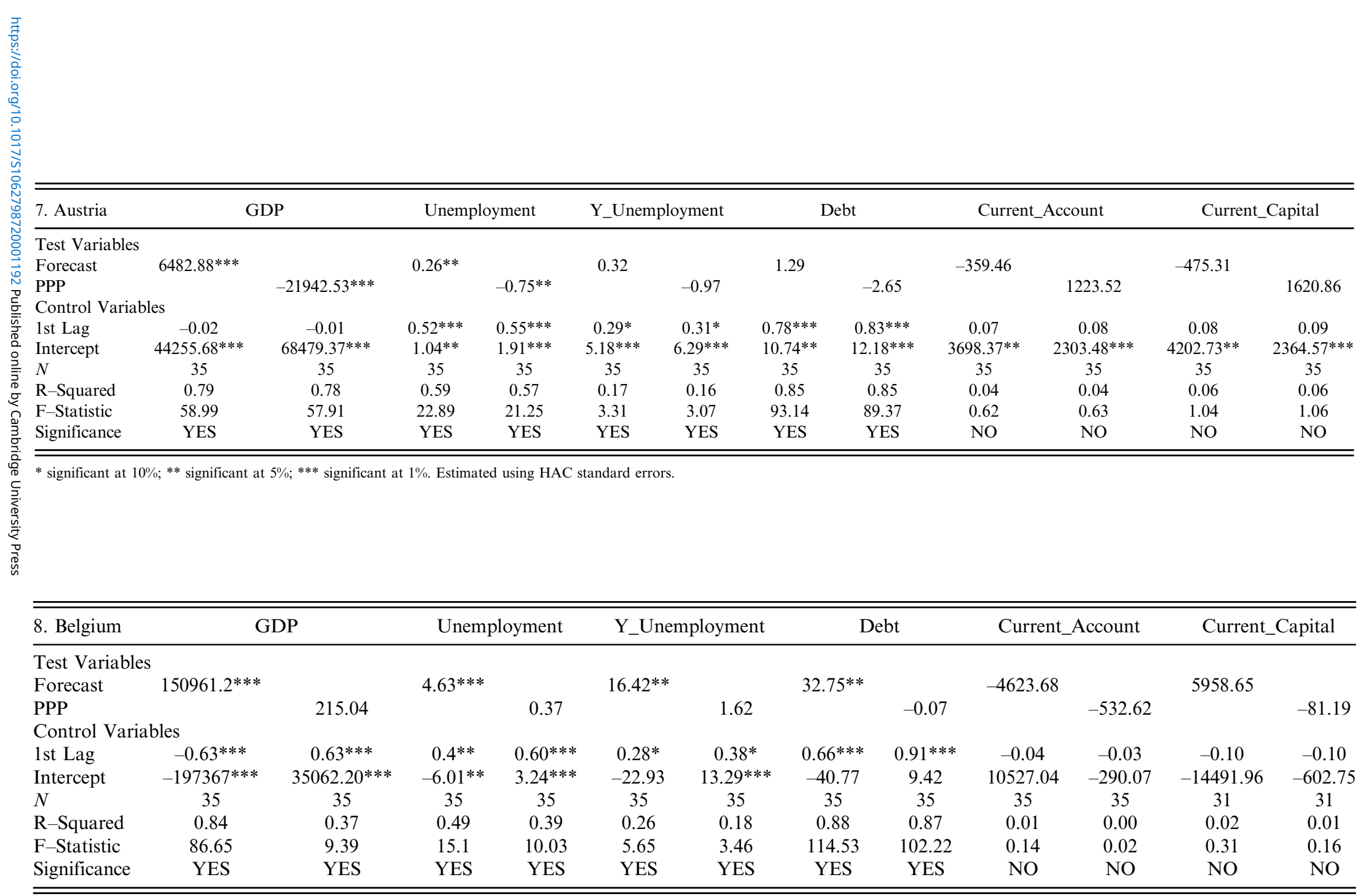

* significant at 10\%; ** significant at 5\%; *** significant at 1\%. Estimated using HAC standard errors. Data for Capital Account in 2007 could not be obtained. 


\begin{tabular}{|c|c|c|c|c|c|c|c|c|c|c|c|c|}
\hline 9. France & \multicolumn{2}{|c|}{ GDP } & \multicolumn{2}{|c|}{ Unemployment } & \multicolumn{2}{|c|}{ Y_Unemployment } & \multicolumn{2}{|c|}{ Debt } & \multicolumn{2}{|c|}{ Current_Account } & \multicolumn{2}{|c|}{ Current_Capital } \\
\hline \multicolumn{13}{|c|}{ Test Variables } \\
\hline Forecast & $3448791 * * *$ & & $89.96 * * *$ & & $141.03^{* * *}$ & & 110.17 & & -4671.18 & & -7588.72 & \\
\hline PPP & & $126551.10^{* * *}$ & & $8.44 * * *$ & & $20.17 * * *$ & & $-15.05^{* *}$ & & $59492.57^{* * *}$ & & $62068.95^{* * *}$ \\
\hline \multicolumn{13}{|c|}{ Control Variables } \\
\hline 1st Lag & -0.04 & $0.78 * * *$ & $0.43 * * *$ & $0.85 * * *$ & $0.54 * * *$ & $0.80 * * *$ & $0.92 * * *$ & $0.98 * * *$ & -0.18 & -0.27 & -0.16 & -0.25 \\
\hline Intercept & $176643.5^{* * *}$ & $130711 * * *$ & $-4.00 * *$ & $2.43 * *$ & -3.95 & $7.17 * *$ & -3.56 & 0.59 & -5015.76 & 1271.59 & -4122.87 & 2187.19 \\
\hline$N$ & 35 & 35 & 35 & 35 & 35 & 35 & 35 & 35 & 35 & 35 & 35 & 35 \\
\hline R-Squared & 0.79 & 0.64 & 0.79 & 0.76 & 0.67 & 0.67 & 0.98 & 0.99 & 0.04 & 0.16 & 0.03 & 0.16 \\
\hline F-Statistic & 60.3 & 27.98 & 59.07 & 50.06 & 32.76 & 31.88 & 1011.32 & 1108.47 & 0.61 & 3.11 & 0.44 & 3.14 \\
\hline Significance & YES & YES & YES & YES & YES & YES & YES & YES & NO & YES & NO & YES \\
\hline
\end{tabular}

* significant at $10 \% ; *$ significant at $5 \% ; * *$ significant at $1 \%$. Estimated using HAC standard errors

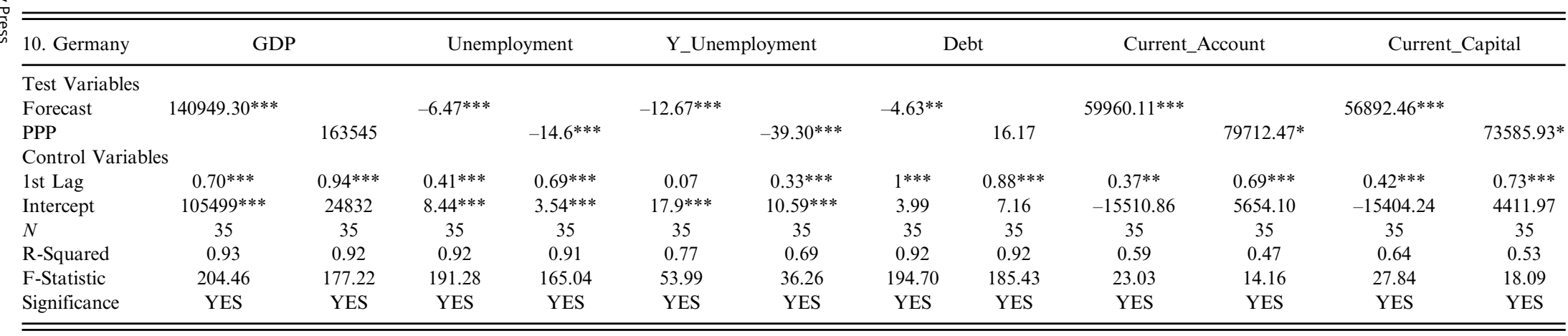

* significant at $10 \% ; * *$ significant at $5 \% ; * * *$ significant at $1 \%$. Estimated using HAC standard errors. 


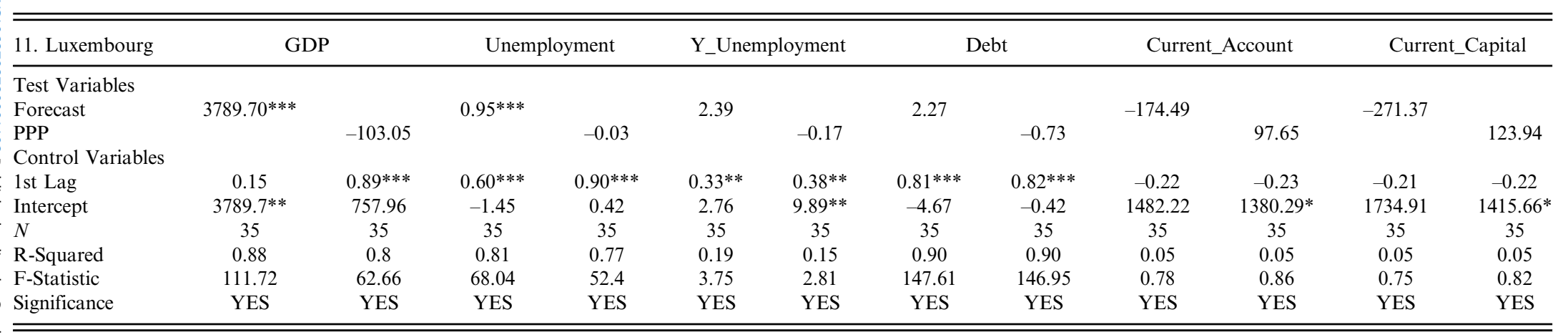

* significant at $10 \% ;{ }^{* *}$ significant at $5 \% ; * * *$ significant at $1 \%$. Estimated using HAC standard errors.

\begin{tabular}{|c|c|c|c|c|c|c|c|c|c|c|c|c|}
\hline 12. The Netherlands & \multicolumn{2}{|c|}{ GDP } & \multicolumn{2}{|c|}{ Unemployment } & \multicolumn{2}{|c|}{ Y_Unemployment } & \multicolumn{2}{|c|}{ Debt } & \multicolumn{2}{|c|}{ Current_Account } & \multicolumn{2}{|c|}{ Current_Capital } \\
\hline \multicolumn{13}{|l|}{ Test Variables } \\
\hline Forecast & $59136.36^{* * *}$ & & $4.04 * *$ & & 3.08 & & 2.93 & & $15902.19 * * *$ & & 15037.67 & \\
\hline PPP & & $105159.4^{* *}$ & & -4.18 & & $-11.87 * *$ & & 3.99 & & -12770.59 & & -47659.94 \\
\hline \multicolumn{13}{|l|}{ Control Variables } \\
\hline 1st Lag & -0.24 & $0.77 * * *$ & $0.70 * * *$ & $0.92 * * *$ & $0.73 * * *$ & $0.77 * * *$ & $0.91 * * *$ & $0.94 * * *$ & $0.45^{* * *}$ & $0.66^{* * *}$ & 0.09 & 0.10 \\
\hline Intercept & $157148 * * *$ & $55253.62 *$ & $-1.18^{*}$ & -0.16 & 0.81 & 0.66 & 4.00 & 4.53 & -4270.68 & 2224.25 & -541.91 & 2297.85 \\
\hline$N$ & 35 & 35 & 35 & 35 & 35 & 35 & 35 & 35 & 35 & 35 & 35 & 35 \\
\hline R-Squared & 0.58 & 0.28 & 0.93 & 0.92 & 0.78 & 0.78 & 0.95 & 0.94 & 0.60 & 0.50 & 0.07 & 0.04 \\
\hline F-Statistic & 21.94 & 6.07 & 204.26 & 173.81 & 55.10 & 55.31 & 275.06 & 274.53 & 23.77 & 16.16 & 1.17 & 0.73 \\
\hline Significance & YES & YES & YES & YES & YES & YES & YES & YES & YES & YES & NO & NO \\
\hline
\end{tabular}

* significant at $10 \%$;* significant at $5 \%$; *** significant at $1 \%$. Estimated using $\mathrm{HAC}$ standard errors. 
advancements and migration of labour-intensive employment to Asia. Overall, results from core members, other than Germany, must be interpreted with particular caution in view of the imprecise nature of forecasting.

The results from Table 2 indicate that five of the original six peripheral members are overvalued on both measures of currency distortion. This is supported by the positive and significant coefficients on both Forecast and PPP, in Table 3, Parts 1-6, when regressed against GDP.

The exception is Ireland where Forecast has a negative and significant coefficient when regressed against $G D P$ and a positive and significant coefficient when regressed against Unemployment. These results are counterintuitive because they suggest that a lower currency value leads to lower GDP and higher unemployment.

This effect may be due to advances in productivity, which add noise to the results. They may also relate to my time-series forecast predicting excessive depreciation of the Irish pound. In practice, Ireland benefited from high levels of foreign investment during the 'Celtic Tiger' period between the 1990s and 2008 (Kirby 2002, 2010). This may have moderated the extent to which the Irish pound depreciated (Eurostat 2018).

$P P P$ supports the expected relationship between currency distortion and Ireland's macroeconomic indicators. This result is intuitive given that the 'Celtic Tiger' period caused economic variables to skew from long-term trends, thereby restricting my model's ability to accurately forecast real exchange rate deviation. In contrast to the time-series forecast, $P P P$ is constructed from theoretical foundations that were able to capture the effect of Ireland's economic boom. Using PPP, GDP has a positive and significant coefficient, my measures of unemployment have negative and significant coefficients and balance of trade measures have positive and significant coefficients. The positive coefficient for Debt is likely to reflect rapid growth in the Irish Economy, which caused debt, as a proportion of GDP, to fall despite appreciation in Ireland's real exchange rate (Trading Economics 2020).

In the case of Spain, Forecast also has a positive and significant coefficient when regressed against Unemployment and Y_Unemployment. This may be due to foreign capital inflows creating employment opportunities.

With the exception of Ireland and Spain, results for unemployment concur with expectations. $P P P$ has a negative and significant coefficient when regressed against Unemployment and $Y_{-}$Unemployment, suggesting that undervaluation leads to lower levels of unemployment. Hence, overvaluation amongst the peripheral members is reflected through higher levels of unemployment in their respective economies.

Results for Debt comply with expectations where significant coefficients for both Forecast and PPP possess negative values. This indicates that nations with overvalued currencies experience greater levels of indebtedness.

The impact of my projected currency distortions on the trade positions of peripheral nations is contrary to hypothesized expectations in four of the six countries. ${ }^{6}$ Across Greece, Italy, Portugal and Spain, the coefficients of both Forecast and

6. The unusual result for Ireland may be due to Forecast unduly undervaluing the Irish Pound. This is addressed in a preceding paragraph. 
PPP take on negative and significant values when regressed against Current_Account and Current_Capital. This suggests that nations with overvalued currencies experience more favourable trade positions. In theory, nations with an overvalued currency have an incentive to import greater quantities of goods and services. Notwithstanding, the negative and prolonged impact of currency distortions on peripheral members of the EMU may have diminished their ability to fund imports. ${ }^{7}$ When coupled with the austerity measures enforced on many peripheral economies, it is likely that peripheral members with overvalued currencies, weak economies and high levels of austerity would have significantly diminished import capacity. In turn, this creates a situation where Germany funds its export driven model through loans to peripheral members.

\section{Conclusion}

Overall, this paper provides valuable insights into the effect of currency distortions, generated by the EMU, on the competitiveness and real economies of Eurozone members. Whilst Germany has clearly benefited from its adoption of the euro, the magnitude of benefits that have flowed towards the other five original core EMU members is less pronounced. Furthermore, my results support the argument that peripheral members may have suffered from their adoption of the euro. This is reflected through lower GDP and generally higher levels of unemployment and debt. The results suggest that peripheral members have been unable to afford large current account deficits. This leads to the situation where Germany largely funds its own exports through the provision of credit to peripheral governments. This parallels the relationship China has with major trading partners such as the United States.

\section{Policy Implications}

Formation of the EMU caused real exchange rates to deviate from their conversion values, subsequently impacting the competitiveness of its members. Core members, notably Germany, benefited at the expense of peripheral members such as Greece, Spain, Portugal and Italy. Johnson (1969) outlines how a common currency can disadvantage certain regions by opening them up to sudden competition in product and factor markets. Whilst this situation is usually alleviated on a national scale through fiscal transfers, the degree to which this can take place in Europe is hindered by current fiscal arrangements within the EMU (De Grawe 2012). Austerity measures have stalled economic recovery by decreasing rather than promoting competitiveness within struggling members (Stiglitz 2016). Proponents of austerity argue that, in order to maintain stability and minimize cross-subsidy, protections on borrowing and fiscal discipline are required within a common currency bloc.

7. Peripheral nations cannot afford a large current account deficit, this causes the coefficient to take on a negative value. 
Nevertheless, the use of austerity must be applied carefully to ensure that weaker regions avoid a dangerous contractionary cycle, which will undermine cohesion efforts and the EU's objective of 'ever closer union' (Lapavitsas et al. 2010). To maintain prosperity and competitiveness within the global economy, Europe should consider mechanisms that would expand its capacity to make timely fiscal transfers between members within existing frameworks.

The International Monetary Fund and European Commission have been particularly critical of Germany's tight fiscal stance, which is contributing to not just European but global economic imbalances (Nienaber 2018). Accordingly, policymakers need to consider substantial changes to the manner in which the Eurozone is administered to ensure the long-term economic and political unity of Europe.

Bernanke (2015) outlines how Germany can help ease current account imbalances by increasing investment in domestic infrastructure. This would have a dual effect. First it would increase the quality of German infrastructure and put Germany on a trajectory of improved growth (Connolly, 2018). Second, it would increase German wages and inflation, which would in turn increase German income and consumption. An increase in German inflation will soften the adjustment process necessary to rebalance European competitiveness whilst increasing economic activity within the entire Eurozone (Bernanke 2015).

Foremost, in accordance with OCA theory, the EMU ought to move towards increased fiscal, budgetary and banking integration capable of reconciling differences generated by the asymmetric productivity of members (Arestis et al., 2003; Arestis and Sawyer 2006a, 2006b, 2006c). Without a system of substantial fiscal transfers, the EMU creates tensions that undermine the EU's efforts to create an economically and politically balanced region (Collignon and Esposito 2014).

It is critical that fiscal transfers are carefully directed towards initiatives that increase productivity and lower unemployment within peripheral members. Sinn (2014) argues that current account and spatial imbalances can only be overcome through fundamental improvements in the productivity and competitiveness of peripheral members. This will reduce the requirement for long-term fiscal transfers.

Whilst greater fiscal federalism offers a way forward, the absence of cultural homogeneity makes enhanced economic union problematic, with Germany and other northern members remaining cautious of a common budget (Deutsche Bundesbank 2013; Rankin 2018). Furthermore, regional differences in unemployment and incomes, within EMU member countries, diminishes the appetite for cross-border fiscal transfers. For instance, a study by the German Economic Institute found that Germany had the greatest wealth inequality in the EMU (Oltermann 2014; DIW Berlin 2014). This has created resistance towards calls for a European finance minister and central budget (Pinnington 2018; Rankin 2018). Critics of a central budget argue that the allocation of resources by unelected bureaucrats in Brussels undermines the fundamental democratic principle of 'no taxation without representation' (Baldwin and Wyplosz 2012; Rankin 2018). A first step 
towards overcoming resistance to fiscal integration is to address inequalities within EMU members.

As the European Monetary Union and European Union are relatively young institutions, time will be required for more robust political and economic systems to be developed. Fiscal integration is a complex process which reduces the autonomy of nation states and risks decision-making being made at high levels that are detached from the requirements of individual regions within EMU members. While I argue that fiscal integration would alleviate some of the economic challenges currently faced by the Eurozone, such assimilation requires careful management and protections to ensure that capital is appropriately directed.

\section{Acknowledgements}

I thank my late supervisor Dr Alex Morris whose kindness and passion for the use of economics to enact positive change are a continual inspiration.

\section{Conflict of Interest}

The author declares he has no conflict of interest.

\section{References}

Arestis P (2007) Is there a New Consensus in Macroeconomics. Basingstoke: Palgrave Macmillan.

Arestis P and Sawyer M (2006a) Alternatives for the policy framework of the euro. In Mitchell W, Muysken J and Veen TV (eds), Growth and Cohesion in the European Union: The Impact of Macroeconomic Policy. Cheltenham, UK: Edward Elgar.

Arestis P and Sawyer M (2006b) Reflections on the experience of the euro: lessons for the Americas. In Vernengo M (ed.), Monetary Integration and Dollarization: No Panacea. Cheltenham, UK: Edward Elgar.

Arestis P and Sawyer M (2006c) Macroeconomic policy and the European Constitution. In Arestis P and Sawyer M (eds), Alternative Perspectives on Economic Policies in the European Union. Basingstoke: Palgrave Macmillan.

Arestis P and Sawyer M (2012) The Euro Crisis. Basingstoke, Hampshire: Palgrave Macmillan.

Arestis P, Ferrari F, Fernando de Paula F and Sawyer M (2003) The Euro and the EMU: Lessons for Mercusor. In Arestis P and Fernando de Paula L (eds), Monetary Union in South America: Lessons from EMU. Cheltenham, UK: Edward Elgar Publishing.

Atkinson R (2001) The emerging 'urban agenda' and the European spatial development perspective: towards an EU urban policy? European Planning Studies 9(3), 385-406.

Baldwin R and Wyplosz C (2012) The Economics of European Integration, 4th Edn. New York: McGraw-Hill Education. 
Bernanke B (2015) Germany's trade surplus is a problem. Brookings Institution. April 3. Available at: www.brookings.edu/blog/ben-bernanke/2015/04/03/ germanys-trade-surplus-is-a-problem/ (accessed 9 January 2018).

Bohme, H. (2018) Opinion: Germany's boom and Europe's problems. Deutsche Well. Available at: www.dw.com/en/opinion-germanys-boom-and-europesproblems/a-42109886 (accessed 17 January 2018).

Collignon S and Esposito P (2014) Competitiveness in the European Union. London, UK: Routledge.

Connolly K (2018) We are becoming a joke': Germans turn on Deutsche Bahn. The Guardian. Available at: www.theguardian.com/world/2018/dec/20/trains-on-timegermans-deutsche-bahn-railway (accessed 2 January 2019).

De Grawe P (2012) Economics of Monetary Union, 9th Edn. Oxford: Oxford University Press.

Deutsche Bundesbank (2013) The German Economy's Current Account Surplus. Deutsche Bundesbank. Annual Report 2013.

DG Regio (2017) The EU's main investment policy. European Commission. Available at: http://ec.europa.eu/regional_policy/en/policy/what/investmentpolicy/ (accessed 12 January 2017).

DIW Berlin (2014) Persistently high wealth inequality in Germany. German Institute for Economic Research. Available at: www.diw.de/en/diw_01.c.438772.en/ persistently_high_wealth_inequality_in_germany.html (accessed 3 June 2018).

ECB (European Central Bank) (2006) Fiscal policies and financial markets. Monthly Bulletin, February.

ECB (European Central Bank) (2012) Euro area labour markets and the crisis. Structural Issues Report. October. Available at: www.ecb.europa.eu/pub/pdf/ other/euroarealabourmarketsandthecrisis201210en.pdf (accessed 18 January 2018).

ECB (European Central Bank) (2018a) Inflation dashboard. Available at: www. ecb.europa.eu/stats/macroeconomic_and_sectoral/hicp/html/inflation.en.html? hasFlash=true\& (accessed 19 April 2018).

ECB (European Central Bank) (2018b) The definition of price stability. Available at: www.ecb.europa.eu/mopo/strategy/pricestab/html/index.en.html (accessed 19 April 2018).

Economist (2017) Why German current-account surplus is bad for the world economy. The Economist. Available at: www.economist.com/news/leaders/ 21724810-country-saves-too-much-and-spends-too-little-why-germanys-currentaccount-surplus-bad (accessed 14 May 2018).

European Commission (2011) Quarterly Report on the Euro Area. Volume 10. No. 3. European Commission Directorate-General for Economic and Financial Affairs.

European Commission (2012) Macroeconomic imbalances procedure. Available at: http://ec.europa.eu/economy_finance/economic_governance/macroeconomic_ imbalance_procedure/index_en.htm (accessed 18 January 2018).

European Parliament (1995) Madrid European Council Meeting, 15 and 16 December 1995, Presidency Conclusions. Available at: www.europarl.europa. eu/summits/mad1_en.htm (accessed 21 January 2018).

Eurostat (2017) Balance of Payments Statistics. Available at: http://ec.europa.eu/ eurostat/statistics-explained/index.php/Balance_of_payment_statistics (accessed 9 January 2018).

Eurostat (2018) Eurostat Database. Available at: http://ec.europa.eu/eurostat/data/ database (accessed 15 January 2018). 
Goldman Sachs Economics Research (2013) European Economics Analyst. 17 January, No. 03.

IMF (2014) 2014 Article IV Consultation-Staff Report; Press Release; and Statement by the Executive Director for Germany. IMF Country Report No. 14/216. July 2014. International Monetary Fund.

James H (2012) Making the European Monetary Union: The role of the Committee of Central Bank Governors and the Origins of the European Central Bank. London: Belknap Press.

Johnson H (1969) The Case For Flexible Exchange Rates. June 1969. Federal Reserve Bank of St. Louis.

Kirby P (2002) The Celtic Tiger in Distress: Growth and Inequality in Ireland. Basingstoke: Palgrave Macmillan.

Kirby P (2010) Celtic Tiger in Collapse: Explaining the Weaknesses of the Irish Model, 2nd Edn. Basingstoke: Palgrave Macmillan.

Kitsantonis N (2018) Greece adopts new austerity measures to placate creditors. The New York Times, 15 January. Available at: www.nytimes.com/2018/01/15/world/ europe/greece-austerity-bailout.html (accessed 16 January 2018).

Lapavitsas C, Kaltenbrunner A, Lindo D, Michell J, Painceira J, Pires E, Powell J, Stenfors A and Teles N (2010) Eurozone crisis: beggar thyself and thy neighbour. Journal of Balkan and Near Eastern Studies 12, 321-373, 10.1080/19448953.2010. 510012.

Lucey C (2017) Never mind China, it's in Europe, via Germany, that the real currency distortion occurs. Hibernia Forum. Available at: www.hiberniaforum.ie/ never-mind-china-europe-via-germany-real-currency-distortion-occurs/ (accessed 9 January 2018).

Mankiw G (2008) New Keynesian Economics. The Encyclopedia of Economics. Library of Economics and Liberty. Available at: www.econlib.org/library/Enc/ NewKeynesianEconomics.html (accessed 15 January 2018).

Neal L (2007) The Economics of Europe and the European Union. Cambridge: Cambridge University Press.

Nienaber M (2018) IMF pressures German government to invest more to reduce trade surplus. Reuters. Available at: www.reuters.com/article/us-germanyeconomy-imf/germany-should-invest-more-to-reduce-current-account-surplusimf-idUSKCN1IF1CE (accessed 14 May 2018).

OECD (1992) Programme on Technology and the Economy. Paris, France: Organisation for Economic Cooperation and Development.

OECD (2015) In it together: why less inequality benefits all. Organisation for Economic Cooperation and Development. Available at: www.oecd-ilibrary.org/ employment/in-it-together-why-less-inequality-benefits-all_9789264235120-en (accessed 25 November 2017).

OECD (2018) OECD Data. Current Account Balance. Available at: https://data. oecd.org/trade/current-account-balance.htm (accessed 22 May 2018).

OFX (2018) Historical Exchange Rates. Available at: www.ofx.com/en-gb/forexnews/historical-exchange-rates/ (accessed on 22 May 2018).

Oltermann P (2014) Wealth inequality in Germany likely to be higher than previously thought. The Guardian. Available at: www.theguardian.com/world/2014/ oct/23/wealth-gap-inequality-germany-higher-study (accessed 1 June 2018).

Pinnington R (2018) EU superstate near: Schulz vows to create Brussels finance minister in MASSIVE power grab. Available at: www.express.co.uk/news/world/ 904043/European-Union-federalist-superstate-Martin-Schulz-Brussels-financeminister (accessed 13 January 2018). 
Rankin J (2018) Europe should have its own economy and finance minister, says EC. The Guardian. Available at: www.theguardian.com/business/2017/dec/06/europeshould-have-its-own-minister-of-economy-and-finance-says-ec (accessed 1 June 2018).

Reuters (2017) No debt relief for Greece, Germany's deputy finance minister says. Reuters World News. Available at: https://uk.reuters.com/article/uk-eurozonegreece-germany/no-debt-relief-for-greece-germanys-deputy-finance-ministersays-idUKKBN1650AU (accessed 12 January 2017).

Sachgau O and Skolimowski P (2018) Germany's jobless rate drops to record low as economy booms. Bloomberg. Available at: www.bloomberg.com/news/articles/ 2018-01-03/german-unemployment-rate-drops-to-record-low-as-economy-booms (accessed 17 January 2018).

Sinn H (2010) Rescuing Europe, CESifo Forum Special Issue. August. pp. 1-22. Available at: www.cesifo-group.de/DocDL/Forum-Sonderheft-Aug-2010.pdf (accessed 18 January 2018).

Sinn H (2014) Austerity, growth and inflation: remarks on the Eurozone's unresolved competitiveness problem. The World Economy 37, 1-13, doi: 10.1111/ twec. 12130 .

Sinn H and Koll R (2000) The euro, interest rates and European economic growth. CESifo Forum 1(3), 30-31. Available at: www.cesifo-group.de/DocDL/ Forum300-s11.pdf (accessed 18 January 2018).

Stiglitz J (2016) The Euro and its Threat to the Future of Europe. London, UK: Allen Lane.

Stock J and Watson M (2011) Introduction to Econometrics, 3rd Edn. New York: Pearson Education.

Taylor M (2003) Purchasing power parity. Review of International Economics 11(3), 436-452.

Trading Economics (2020) Ireland Government Debt to GDP 1980-2018 Data. Available at: https://tradingeconomics.com/ireland/government-debt-to-gdp (accessed 29 February 2020).

\section{About the Author}

Christopher Day is a $\mathrm{PhD}$ student at the University of Sydney Business School. Formerly, Christopher was a researcher for the Department of Industry, Innovation and Science at the Australian Embassy in Washington, DC, where he undertook research in the areas of spatial economics and innovation policy. Prior to this, Christopher worked as a consultant for an economics and public affairs consultancy in London where he focused on industrial policy and productivity. Before moving into industry, Christopher was an academic in Sydney, where he taught in the areas of quantitative business analysis, corporate evaluation and international financial management and conducted research in the fields of corporate finance and accounting. Christopher holds a Master of Philosophy from the University of Cambridge and graduated with First Class Honours and the University Medal from the University of Technology Sydney. 